\title{
Innovation in Management Plans for Community Conserved Areas: Experiences from Australian Indigenous Protected Areas
}

\author{
$\underline{\text { Jocelyn Davies }}^{1}, \underline{\text { Rosemary Hill }}^{1}, \underline{\text { Fiona J. Walsh }}^{1}$, Marcus Sandford $^{2,3}$, Dermot Smyth $^{4,5}$ and Miles C. Holmes $^{6,7}$
}

\begin{abstract}
Increasing attention to formal recognition of indigenous and community conserved areas (ICCAs) as part of national and/or global protected area systems is generating novel encounters between the customary institutions through which indigenous peoples and local communities manage these traditional estates and the bureaucratic institutions of protected area management planning. Although management plans are widely considered to be important to effective management of protected areas, little guidance has been available about how their form and content can effectively reflect the distinctive socio-cultural and political characteristics of ICCAs. This gap has been particularly apparent in Australia where a trend to rapidly increased formal engagement of indigenous people in environmental management resulted, by 2012, in 50 indigenous groups voluntarily declaring their intent to manage all or part of their estates for conservation in perpetuity, as an indigenous protected area (IPA). Development and adoption of a management plan is central to the process through which the Australian Government recognizes these voluntary declarations and invests resources in IPA management. We identified four types of innovations, apparent in some recent IPA plans, which reflect the distinctive socio-cultural and political characteristics of ICCAs and support indigenous people as the primary decision makers and drivers of knowledge integration in IPAs. These are (1) a focus on customary institutions in governance; (2) strategic planning approaches that respond to interlinkages of stewardship between people, place, plants, and animals; (3) planning frameworks that bridge scales by considering values and issues across the whole of an indigenous people's territory; and (4) varied communication modes appropriate to varied audiences, including an emphasis on visual and spatial modes. Further research is warranted into how governance and management of IPAs, and the plans that support these processes, can best engender adaptive management and diverse strong partnerships while managing the risk of partners eroding local control.
\end{abstract}

Key Words: aboriginal land management; community-based conservation; indigenous community conserved areas; indigenous protected areas; management effectiveness; planning

\section{INTRODUCTION}

Management plans are widely considered to be important for effective management of protected areas (Oltremari and Thelen 2003, Thomas and Middleton 2003, Lockwood 2006, Leverington et al. 2008, 2010, Stoll-Kleemann 2010). Although the existence of a management plan is not in itself a good predictor of effective management, it may underpin other factors that are good predictors such as adequate infrastructure, monitoring and evaluation, management skills, a clear work program, and a supportive political environment (Leverington et al. 2010). However, many protected areas do not have documented management plans (Leverington et al. 2008). Further, when management plans do exist, critics point out that they are often little used (Clarke 1999, 2000, Fallding 2000, Oltremari and Thelen 2003) and may be unusable (Clarke 1999).

Accessible guidance for the form and content of protected area management plans (Thomas and Middleton 2003, Lockwood 2006) draws primarily on experiences from governmentmanaged protected areas. Little specific guidance is available about the characteristics that management plans should have to be appropriate to indigenous and community conserved areas (ICCAs; Kothari 2006, Berkes 2009a, IUCN 2009) in which communities, rather than government, are the major decision makers. Our research contributes to addressing that gap by identifying innovations in the format and content of management plans that have emerged from indigenous protected areas (IPAs) in Australia through novel encounters between the customary institutions through which indigenous peoples manage their traditional estates and the bureaucratic institutions of protected area management planning.

\section{ICCAs and IPAs}

Indigenous protected areas (IPAs) have much in common with the definition adopted by the International Union for the Conservation of Nature (IUCN) for ICCAs, that is "natural and/or modified ecosystems containing significant biodiversity values, ecological services and cultural values that are voluntarily conserved by indigenous and mobile or local communities through customary laws or other effective means" (IUCN 2009). IUCN guidelines recognize, somewhat controversially (Locke and Dearden 2005), that ICCAs are legitimate inclusions in national and global protected area 
Fig. 1. Location of declared indigenous protected areas (IPA) and IPA Consultation Projects (proposals), May 2012, with names of IPAs and proposals mentioned in the text.

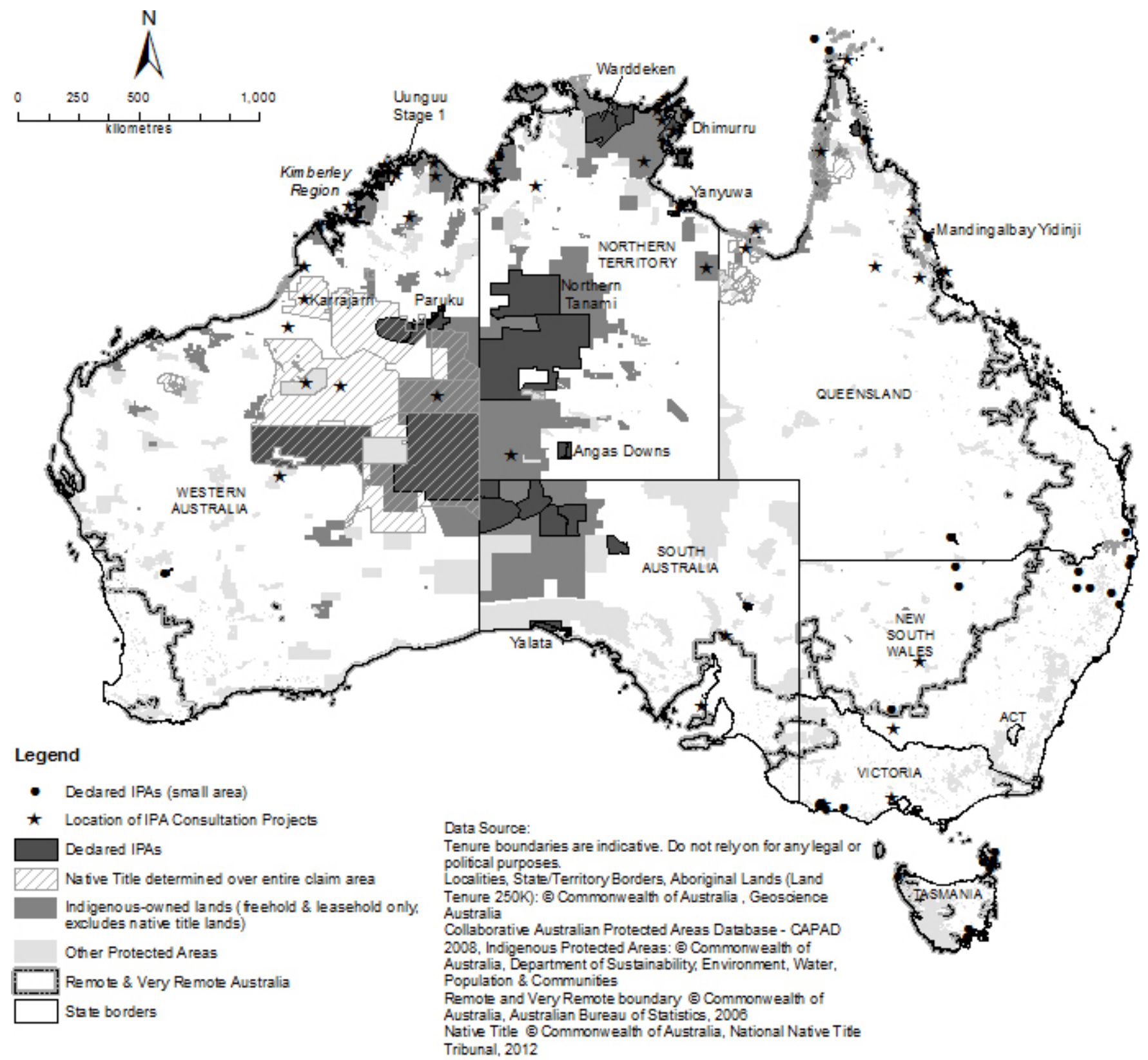

systems (Berkes 2009a). This recognition is consistent with a global paradigm shift in protected area governance over the past two decades toward greater involvement of indigenous people and other local communities (Phillips 2003, Dearden et al. 2005).

An IPA is defined by the Australian Government as an "area of land and/or sea over which the indigenous traditional owners or custodians have entered into a voluntary agreement with the Australian Government for the purposes of promoting biodiversity and cultural resource conservation" (Hill et al. 2011:1). Indigenous representatives have defined IPAs differently in their engagements with Australian policy, in ways that do not rely on government recognition (Szabo and Smyth 2003, Hill et al. 2011). However, the government definition is very pertinent to our focus on the form and content 
of management plans. This is because a management plan, endorsed by traditional owners, is considered by the Australian Government to demonstrate that there are effective nonstatutory means for managing the area, as is required if areas that have no statutory basis for management are to meet the IUCN protected area definition (Dudley 2008). The IPA management plans provide a basis for formal government recognition of indigenous lands as part of the Australian national system of protected areas and are also seen by the Australian Government as an important mechanism for supporting and invigorating the use of indigenous ecological knowledge (IEK) in biodiversity conservation (ANAO 2011). By 2011, 50 declared IPAs (Fig. 1) comprised 3.4\% of the Australian continent and over $25 \%$ of the total area in the Australian terrestrial protected area system, the National Reserve System (NRS; AG 2011). Rapid growth in the number and area of IPAs over the first decade of this millennium is a manifestation of one of four standout trends identified in Australian environmental management: the increased formal involvement of indigenous people (ASEC 2011).

Formal incorporation of ICCAs into national protected area systems raises issues about how indigenous people might remain in control of management, integrate their own knowledge with other inputs and influences on management, and strengthen their capacity to address contemporary threats to biodiversity and heritage values (Berkes 2009a). We approached these issues of control, knowledge, and capacity through the lens of IPA management plans. We examined how the form and content of planning documents, artifacts that typically reflect distinctive ways of thinking and doing that are characteristic of western societies (Henrich et al. 2010), may contribute to addressing these issues. Lessons from Australian experience with IPA management plans are expected to be valuable for other settings in which formal recognition by governments of ICCAs is at an earlier stage.

\section{Considerations for effective ICCA management plans}

The process used for planning has a deep influence on outcomes for empowerment or disempowerment of indigenous people (Lane 2006, Hibbard et al. 2008). However, the format and content of planning documents are also important: decisions and directions established in a planning process are less likely to be overlooked, forgotten, or subverted if they are robustly reflected in a plan (Fallding 2000).

Commentators emphasize that protected area management plans should be action oriented, practical, working manuals that set out what actions will be taken, how, where, when, and by whom (Clarke 2000, Fallding 2000, Thomas and Middleton 2003). However, management plans that are overly prescriptive are quickly outdated and may also provide little guidance for situations that are unanticipated at the time the plans are developed. Effective plans cannot be static documents. They need to promote learning and adaptation in management given incomplete information and pervasive uncertainty in social-ecological systems, including threats to protected area values, opportunities for management action, and endowments of management resources (Berkes et al. 2003).

Although success in community-based conservation is judged differently by various stakeholders, achievement of local control and a style of management appropriate to the local context are widely considered to be important dimensions (Berkes 2004, Axford et al. 2008). Management plans for ICCAs should reflect the defining features identified (Berkes $2009 a$, IUCN 2009) for this protected area governance type. That is, plans should provide for the community that has close cultural or livelihood connections with the area to have an ongoing major role in decisions, as well as promoting decisions that result, directly or indirectly, in conservation outcomes.

Governance, that is, "the powers, authorities and responsibilities exercised by organizations and individuals" (Lockwood 2010:755) or, in other words, who makes decisions about what happens and how those decisions are made (Borrini-Feyerabend 2008) is not established in ICCAs by statutes, regulations, and corporate policies unlike the situation for government-managed protected areas. Management plans for ICCAs thus cannot be concerned only with what actions will be taken to promote conservation. To secure local control over management of ICCAs, management plans need to explicate, if not re-establish, indigenous or local community governance.

Scientific input is important to ensure that ICCA management plans support conservation given new threats from globalization and habitat loss to biodiversity values that may have formerly been conserved as an indirect consequence of indigenous or local people's management for tangible and intangible livelihood needs. Cross-sectoral and cross-scale partnerships are important because local management alone cannot address new and pervasive threats to biodiversity and cultural heritage that emanate from deeper level institutions and larger scale systems (Berkes 2007). However, if they are to be the primary decision makers, indigenous people need to be the prime drivers of knowledge integration, as is also increasingly acknowledged in other contexts (Bohensky and Maru 2011). Further, the diversity of interests within communities (Agrawal and Gibson 1999) suggests that effective plans need to recognize multiple objectives, establish criteria for assessing trade-offs among them, and provide for conflict resolution.

These contextual factors indicate that ICCA plans need to bridge boundaries between the knowledge systems of indigenous owners and custodians and the social institutions that these are embedded in, and those of partners (Berkes 2009b). Trust building, deliberation, and negotiation are 
widely cited as critical for coherent action in dynamic multiparty contexts (Armitage 2007, Berkes 2007, Raymond et al. 2009, Innes and Booher 2010). Effective plans should reflect the importance of these factors.

Four types of innovations that are apparent in some recent IPA management plans are likely to contribute to the effectiveness of these plans. The innovations are: (1) a focus on customary institutions in governance; (2) strategic planning approaches that respond to interlinkages of stewardship between people, place, plants, and animals; (3) planning frameworks that bridge scales, encompassing all of an indigenous people's territory; and (4) varied communication modes appropriate to varied audiences, including an emphasis on visual and spatial modes.

\section{INSTITUTIONAL CONTEXT FOR IPA MANAGEMENT PLANS}

\section{Indigenous land rights and livelihoods}

With key exceptions, IPAs have been declared over lands in which indigenous people's proprietary rights are recognized by governments as freehold, leasehold, or registered native title. Indigenous rights to these lands are held collectively by incorporated indigenous groups or are held in trust for unincorporated groups through statutory mechanisms. For convenience, we refer to these groups as traditional owners even though not all are constituted in ways that reflect customary land and sea ownership principles. Tenures and governance structures are diverse because the six states, rather than the Australian (federal) Government, have prime responsibility for land tenure and management under Australia's constitution. The Australian Government has relatively great power in Australia's territories compared to its states. This has been important to statutory land claim processes that have resulted in $50 \%$ of the Northern Territory being recognized as indigenous-owned land. The Australian Government has also exercised substantial influence nationally on indigenous engagement in environmental management by leading intergovernmental processes, attaching conditions to fiscal distributions and grant programs, and funding purchase of lands for indigenous groups.

Indigenous-owned lands and IPAs are distributed all over Australia. However, the indigenous land holdings and IPAs that are located in the $80 \%$ of the continent that is sparsely populated and remote, or very remote from services (ABS $2010 a$, hereafter termed remote), are substantially larger than those in other regions (Fig. 1). This reflects the impact of physical geography and colonization on indigenous peoples (Davies 2003, Altman et al. 2007, Smith 2008, Taylor et al. 2011). Arid or tropical monsoonal climates and low soil fertility mean that large areas of Australia are relatively unproductive for introduced agricultural systems and were never alienated to nonindigenous interests. Habitat loss through land clearing has not been significant on most of these remote lands. However, introduced species and changes to fire regimes resulting from reduced indigenous economic dependence on hunting and gathering, and on the burning practices that are integrally associated with that customary mode of food production have had an impact on biodiversity values, particularly mammal diversity (Burbidge et al. 1988, Bird et al. 2008, Ritchie 2009). Three quarters of the rapidly growing indigenous population, which comprises $2.5 \%$ of Australians (ABS 2010b, 2010c), live in rural and urban regions. In such areas, indigenous-owned lands mostly comprise small parcels in fragmented landscapes, including some parcels with significant biodiversity and cultural values. Indigenous people fare substantially worse than other Australians across all social and economic indicators (Maru and Chewings 2011, SCGRSP 2011). The diversity of landbased enterprises, generally very small scale, that exist on indigenous-owned land, the numerous mining agreements that provide financial return to indigenous groups through payment of royalty equivalents or negotiated compensation, or the substantial investment from social sectors of governments have little impact on this situation (Gorman et al. 2008, Holcombe et al. 2011, ILC 2011, Koenig et al. 2011).

Evidence supports indigenous people's view that the health of their people and their country are integrally related and indicates that engagement in "caring for country" can be a pathway that improves indigenous people's health (Burgess et al. 2009, Berry et al. 2010, Davies et al. 2011). The term "country" (Stanner 1965, Myers 1986, Rose 1996, Muller 2008) is widely used by indigenous people to encapsulate land, waters, plants, and animals together with multifaceted relationships that link people and various elements of their customary estates as described by Prober et al. (2011) and Holmes and Jampijinpa (2013). "Caring for country" involves the maintenance of these relationships (Young 1987) and is also used to refer to a wide array of natural and cultural resource management activities that draw on IEK, science, or conservation management knowledge (Davies et al. 2011, Ens et al. 2012, Gorman and Vemuri 2012) often under the epithet "two-way" (Muller 2012, Preuss and Dixon 2012).

Cultural services outcomes (sensu MEA 2003) sought by traditional owners from their country include identity, pride, spiritual renewal, enhanced physical health, psychological well-being, and education of children through intergenerational transfer of indigenous ecological knowledge (Rose 1996, Walsh and Mitchell 2002, Peterson 2005, Hunt et al. 2009). Traditional owners also seek economic outcomes from their country, such as an abundance of animal species that are valued as food (Wilson et al. 2004), paid work that engages young people with traditional estates (Luckert et al. 2007, Sithole et al. 2008, Gorman and Vemuri 2012), and payment to elders for their cultural leadership and IEK teaching roles (Douglas 2011). The Australian Government's IPA Program takes 
advantage of the interface between these longstanding aspirations and government goals for biodiversity conservation (Szabo and Smyth 2003, Gilligan 2006). It was catalyzed by the realization, in the mid-1990s, that the NRS could not include a comprehensive, adequate, and representative sample of all Australia's biogeographical regions unless it included some lands in which governments had recognized indigenous people's proprietary rights (Thackway et al. 1996, Szabo and Smyth 2003). The appeal of IPAs to indigenous people, evidenced by a steady growth in the number of IPAs since the first was declared in 1998 (Fig. 2), is explained by the effectiveness of the indigenous engagement methods that the program has developed (Gilligan 2006, ANAO 2011, Smyth 2011, Ens et al. 2012) and a paucity of alternative resources that indigenous people can readily access to support their country-based aspirations (Luckert et al. 2007, Ens et al. 2012).

Fig. 2. Indigenous protected area (IPA) Declarations by year and mean length (years) of IPA Consultation Projects (proposals).

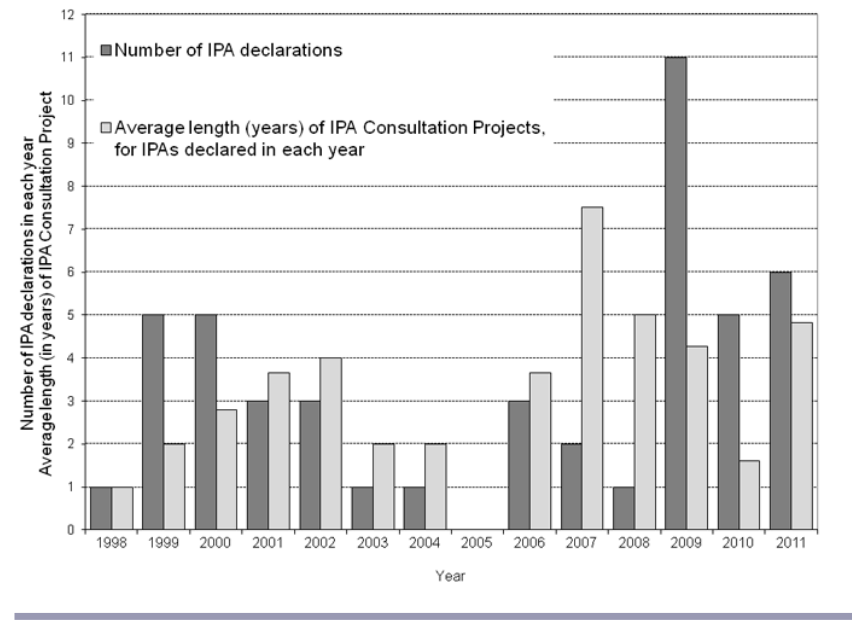

\section{Development of IPA management plans}

Management planning is a critical pathway to IPA declaration. The Australian Government IPA Program is the key enabler (Gilligan 2006, Ross et al. 2009). It resources indigenous groups, through grant funding, administrative assistance, and specialist advice (ANAO 2011), to consider whether establishing an IPA would be viable and would fit with their goals and aspirations, and to implement an agreed program of works on declared IPAs. Development of a management plan is integrated with the process through which indigenous groups decide whether or not to make a voluntary declaration of their intent to manage their land in perpetuity for conservation of biological diversity and associated cultural heritage (Szabo and Smyth 2003, ANAO 2011). The
Australian Government requires that the management plan classify the IPA into one or more of the six IUCN protected area management categories (Dudley 2008) thus providing a benchmark for management approaches (ANAO 2011).

Participatory planning (Walsh and Mitchell 2002, Moorcroft et al. 2012, Preuss and Dixon 2012) contributes to ensuring that traditional owners collectively and robustly grant free, prior, and informed consent for an IPA declaration. To meet the needs of diverse groups, the IPA Program has taken a flexible approach to how this planning is undertaken, and how long it takes (ANAO 2011). This is indicated in Figure 2 by average duration of the planning and consultation processes associated with developing a management plan and other preparations for IPA declaration. Overall these processes extended for an average of 3.5 years for each IPA declared up to December 2011 and ranged from < 1 year to 13 years. Grant funding, between $\mathrm{A} \$ 50,000$ and $\mathrm{A} \$ 190,000$ per year, has paid for the engagement of planning facilitators, consultation meetings, and family visits to country to renew knowledge. Initial grants for management works may also be provided during the consultation and planning phase. No requirements are specified for how IEK should be incorporated into plans, and no penalty is incurred if traditional owners decide not to proceed to IPA declaration. The IPA Program makes independent verifications to ensure that proposed declarations are in accordance with traditional owners' wishes. The final management plan, endorsed by traditional owners, provides the basis for an agreement with the Australian Government about grant funding and other support for management. Streamlined administration means that a single agreement may encompass grants from the IPA Program, the national Indigenous Heritage Program, and the Working on Country Program. The latter funds training and employment of younger indigenous people in environmental management, typically as a workforce of community-based rangers, in almost half of the declared IPAs (ANAO 2011).

In most cases, neither IPA planning facilitators nor the coordinators engaged to facilitate management in declared IPAs are traditional owners. They are typically nonindigenous people trained in ecological science or community development. They may be staff of, or consultants to, an organization constituted directly by the traditional owner group, or in some cases a conservation NGO. However, they are often employed or engaged by regional-level statutory and nonstatutory indigenous representative organizations that have key roles in bridging (Berkes 2009b) across knowledge system boundaries, spanning governance levels in relation to conservation, and all other uses of indigenous-owned lands. As a result of their record of success in achieving outcomes that are important to their constituents, notably land rights gains, these regional organizations are often trusted advisors to traditional owners. Their staff act as brokers (Woodward 2008, Maru and Davies 2011), communicating information to 
and from traditional owner groups and ensuring that any proposed land use is in accordance with their wishes. Many traditional owner groups, particularly in remote regions, learn about the IPA Program through these regional organizations, and the organizations commonly have a direct role in the management of IPAs whose traditional owners are not incorporated or who have limited administrative capacity. For example the Central Land Council is resourced, through grant funding and a statutory mechanism, to employ IPA managers or coordinators, planning facilitators, ranger coordinators, and community-based rangers for three large IPAs or IPA proposals in the southern Northern Territory. The Kimberley Land Council is a nonstatutory organization that carries out these roles in the north of western Australia.

Traditional owners and the staff of bridging organizations report multiple ecological, social, and cultural benefits from their IPAs (Gilligan 2006, Ross et al. 2009, Hunt 2010, WLM 2010, Smyth 2011, Hoffmann et al. 2012). Nevertheless, government and traditional owner agendas can be hard to reconcile (Muller 2008, 2012, Smyth 2011, Gorman and Vemuri 2012). One in-depth analysis (Walker 2011) found that traditional owners and partners who participated in a review of management effectiveness of the Northern Tanami IPA agreed that management should give priority to objectives that are of prime importance to traditional owners. However, all participants also agreed that traditional owners' objectives had received little attention compared to the biodiversity and heritage conservation goals of the IPA Program, which, because of funding accountabilities, were also reflected in the goals of the bridging organization (Walker 2011). Revision of that IPA's initial management plan has been able to draw directly on the lessons from that analysis.

\section{The need for guidelines for IPA management plans}

A review of the first decade of the IPA Program observed that it "seems to trigger a very positive and enthusiastic response from people because of its inherent respect for the decision making role of the indigenous elders and the empowerment and autonomy provided in the formulation and implementation of the Management Plan" (Gilligan 2006:42). However, IPA plans have not always effectively conveyed this decision making role, empowerment, and autonomy. One reason is that early IPA management plans tended to reflect the format and content of those for government-managed protected areas (Lockwood 2006). This orthodoxy was influenced by the IPA Program's cautious attitude during its early years. Program managers perceived a risk that IPAs might be seen by stakeholders as inferior to other protected areas if IPA plans departed radically from familiar forms (Bruce Rose, IPA Program Director, personal communication).

Perusal of early IPA plans indicated several issues that would limit their appeal to indigenous people because they were not congruent with indigenous epistemologies. For example, most early IPA plans adopted a conventional distinction between natural and cultural values, reflecting a foundational principle of modernist western thought that can make deep crosscultural communication difficult (Ingold 2000, DavidsonHunt and Berkes 2002, West and Brockington 2006). The strongest focus in early plans was often on natural values and on actions to address invasive species and inappropriate fire regimes. Indigenous people's attitudes toward these issues, which tend to be different to those of western-trained conservation managers (e.g., Robinson et al. 2005), were sometimes quite obscure. Early plans also tended to lack clear policies or actions to maintain or invigorate cultural practices that were invariably important to traditional owners. Further, some were silent about who was responsible for implementation, or else the plan was unclear about the accountability of coordinators or management staff to traditional owners.

Concerns about such matters led IPA program managers to initiate the development of guidelines for use by traditional owners and IPA planners (Hill et al. 2011) with the aim of ensuring that management plans reflected the distinctive characteristics of IPAs. In the course of developing those guidelines, we identified innovations that are apparent in some recent IPA management plans.

\section{METHODS}

We identified innovations in IPA management plans through a two-day national workshop convened by the IPA Program in collaboration with the Commonwealth Scientific and Industrial Research Organisation (CSIRO; Walsh et al. 2011). This involved 20 IPA traditional owners, conservation planners, and other professionals who the conveners considered, on the basis of their professional knowledge of IPA planning and initial examination of a wide array of draft and endorsed IPA plans, to be innovators. Workshop participants presented plans, which they had been involved in developing in the preceding period of about five years, and peer-reviewed other plans. The examined plans included 10 plans for IPAs or proposed IPAs, 2 plans for comanaged parks, 6 regional-scale plans for indigenous traditional territories, and 4 plans for specific management issues on indigenous land or a government-managed protected area. Most of these plans were from remote regions of Australia (Fig. 1) because workshop conveners had concluded that the most innovative plans were being produced in these regions in which limited literacy and relatively strong continuing use of IEK, including through everyday use of indigenous languages, highlighted the complexities inherent in cross-cultural communication. A limitation is that we examined very few plans for IPAs in more densely settled regions in which place-based approaches are equally important, and the nature of IEK, appropriate representation, and authoritative governance is more contested (Carter and Hollinsworth 2009, Carter 2010). 
In peer-reviewing IPA plans, workshop participants identified the elements that they considered were most, or least, useful and for whom. Qualitative methods of conceptual cluster analysis and theme identification (Kumar 2005) were applied during the workshop to identify factors that accounted for the participants' assessments of the various plans. Workshop conveners later examined a broader selection of plans against themes identified during the workshop. We outline themes identified as innovative in that they depart from the format and content of conventional protected area management plans to address distinctive values of IPAs and characteristics of IPA governance and management. No single plan that we examined included all these themes.

\section{INNOVATION IN IPA MANAGEMENT PLANS}

\section{Focus on customary institutions in governance}

Some IPA plans recognize a fundamental and strong role for customary institutions in governance. This reflects the view commonly expressed by traditional owners that only people with the proper customary rights and responsibilities can make decisions about country. Plans embody this view by presenting IPA management as, first and foremost, a story that is being told by traditional owners themselves. The plans often include photographs of and quotations from individual people that signify their authority to speak for the area. Identity and cultural distinctiveness is also conveyed through devices such as a dedication; simple, strong vision statements; and stories that add depth and nuance. These variously recount how the decision about IPA declaration was made and the history leading up to it, express traditional owners' feelings about country, acknowledge ancestral creation-beings that have an ongoing presence on country, and set out hopes and ambitions for future generations.

Plans indicate the diversity in governance structures for IPAs. IPAs on lands that are held in trust for indigenous people through statutory mechanisms are variously governed by committees and boards whose membership is generally drawn from people with customary rights and responsibilities for the area. These governing bodies are commonly presented in the plans as being accountable to the larger group of traditional owners, i.e., by diagrams that show the traditional owner group at the top of decision making structures (Dhimurru Aboriginal Corporation et al. 2008, Preuss and Dixon 2012). In other cases, for example, when an incorporated indigenous group is the landowner or lessee, its governing body usually also governs the IPA. Such is the case with the Yalata IPA, (C. Rodgers, unpublished manuscript), which is declared on land leased to Yalata Community Inc. In contrast to the lack of clarity in some early plans about the accountability of staff, recent plans state more clearly that the role of coordinators or managers, whether employed by the IPA governing body or by a bridging organization, is to implement IPA governing bodies' decisions, often through the work of community-based ranger groups.

\section{Strategic planning for interlinked people, places, plants, and animals}

Strategic planning approaches are being used to address the distinctive socio-cultural characteristics of IPAs. These approaches emphasize high-level purposes, such as vision and intent, rather than attempt to comprehensively address all aspects of management (Lockwood 2006). They do not require any distinction to be drawn between natural and cultural values, obviating the common urge among western-trained conservation planners to delineate goals and practices as either natural or cultural resource management.

The integration of biodiversity conservation with tangible and intangible dimensions of indigenous culture is illustrated in adaptations of conservation action planning (CAP) tools (TNC 2006). For example, Wunambal Gaambera people identified 10 of the most important things, termed focal conservation targets in CAP, for their management of the Uunguu IPA including "Wanjina Wunggurr Law - our culture," "Right way fire," "Aamba and other meat foods," "Bush plants," "Rock art," and "Mangguru (marine turtles) and Balguja (dugong)." These targets address elements of prime importance to traditional owners for their identity and livelihoods. Nested targets encompass management issues that are more familiar to stakeholders whose goals are biodiversity conservation. Traditional owners liken the structure to going hunting for kangaroos: "we also do other things along the way" (Moorcroft et al. 2012; Wunambal Gaambera Aboriginal Corporation, unpublished manuscript). Strategies in a revised draft of the Yalata IPA plan (C. Rodgers, unpublished manuscript), in which CAP tools were not used in planning, show a similar structure. The management plan for Angas Downs IPA is one of very few plans that includes strategies directed at managing the impact of traditional owners' own use of wildlife (Wilson et al. 2005). It integrates indigenous governance and wildlife management science with the aim of increasing populations of animals valued by traditional owners as game (Wilson and Woodrow 2009). Because some such species are considered common by conservation planners, they attract little attention in other management approaches (Finn and Jackson 2011).

\section{Country-based planning that bridges scales}

The term country-based planning refers to a process in which traditional owners identify their aspirations and strategies across the entirety of their traditional territories, unconstrained by the tenures that are recognized by governments (Smyth 2008). This process develops a strategic framework for considering how values and issues beyond the scale of a particular legal land tenure parcel should influence the boundaries adopted for an IPA, identifies impacts from 
nonlocal institutions and processes that need attention in IPA management, and develops strategies that are important for addressing these cross-scale dimensions. Country-based planning helps to overcome IPA planners' reliance on plans and strategies developed by government authorities, with limited input from indigenous people for understanding the regional context of an IPA. It thus helps to redress the key problem, recognized for ICCAs globally (Kothari 2006:567), of customary institutions being undermined by colonial or centralized political systems.

Country-based planning has provided the framework for multitenure IPAs, such as in the Yanyuwa IPA proposal (Bradley and Yanyuwa Families 2007) and the Mandingalbay Yidinji IPA (MYAC 2006), which comprise land under indigenous and nonindigenous tenures, shorelines, and marine areas. Indigenous people's conception of these areas as one country has provided impetus for development of a consistent conservation management framework. Implementation of management plans for such areas necessarily centers on negotiation and partnership.

\section{Communicating to varied audiences}

Risks to traditional owners' authority and control can arise from text-rich plans if these are written in high-level English that traditional owners perceive as a secret language (Christie and Perrett 1996) or contain key words that are open to multiple interpretations (Hoffmann et al. 2012). Many traditional owner groups continue to prefer oral and visual communication modes and tend not to see the value of written plans for their own use. However, IPA management plans have other important audiences including professional and managerial staff of the IPA, government agencies, community service organizations, schools, and researchers.

In response to such issues, IPA planning increasingly tends to generate a suite of documents for different audiences and purposes, as is recommended more generally for protected areas (Thomas and Middleton 2003, Lockwood 2006). A main plan that is succinct and rich with pictures and maps will often be supplemented by a compilation of relevant scientific and technical information, short-term action plans or annual work plans, and conservation and site management plans for particular features and localities.

Indigenous paintings that represent landscapes are being incorporated in IPA management plans alongside topographic maps. Observers often liken these paintings to maps although Sutton (1998a), in a more critical assessment, disagrees. Some IPA planning processes have also developed land use and occupancy maps (Tobias 2010), which is novel in the Australian context in which land claim processes have emphasized indigenous spiritual, rather than economic, geographies. Maps that combine both can have particular impact for nonindigenous audiences in signifying IPAs as landscapes that are under stewardship, because the density of named places, which are often waterholes or other resourcerich landscape patches with important biodiversity conservation values, contrasts with their paucity on standard topographic maps, particularly in remote regions (Walsh 2009).

Locally meaningful icons are being incorporated into plans as mnemonics or guides to content. For example, the plan for the proposed Karajarri IPA uses local idiom to represent traditional owners' various goals: "keeping country healthy" is symbolized by the annual cycle of six seasons (Prober et al. 2011); "keeping culture strong" is symbolized by ngurpa, calling people to ceremony; "having resources for management" is symbolized by yirlpi, making fire; and "looking to the future" is symbolized by palatany ngapa, storing water in trees (Tanya Vernes, WWF Australia, personal communication). Such idioms, and associated symbols, help to promote confidence among traditional owners that they can "read the plan's words by drawing on the ways they have always read the country" (Walsh et al. 2011; Jampijinpa, personal communication).

\section{DISCUSSION}

The innovations described contribute to addressing the need that has been identified (Waylen et al. 2010) for managers of conservation to better understand and adjust to community settings. Indigenous ontologies are recognizable in these innovations through portrayals of leaders and ancestors, spiritual and/or human, whose authority underpins governance, through conservation targets that focus on culturally important species and processes, and through the use of local idiom and imagery. These features, together with a strong focus in many IPA plans on facilitating intergenerational knowledge transmission, integrate aspects of the whole spectrum of the knowledge- practice-belief complex that characterizes IEK (Berkes et al. 2000) into conservation planning. As with other protected areas (Leverington et al. 2010), we do not know the extent to which IPA management plans contribute to conservation and livelihood outcomes beyond their immediate role in underpinning resourcing agreements with the Australian Government. However, we expect that traditional owners will have a relatively greater sense of ownership of management plans and be relatively less likely to revise their intent to manage their lands for conservation, when these kinds of innovations result in IPA plans that reflect their world view.

IPAs and other engagements in environmental management that allow indigenous people to maintain or re-establish sole or substantial control over governance are identified by Hill et al. (2012) as offering the best prospects for IEK to be integrated with other knowledge in ways that promote sustainability in social-ecological systems. The focus on customary institutions in governance that is emerging in some IPA plans emphasizes that IPA governance is not the domain 
of indigenous people per se, but rather of the particular indigenous people who are recognized by others as having rights and responsibilities within the IPA. These rights and responsibilities are underpinned by social relationships of stewardship that are embedded in place-attachments, totemic relationships, and classificatory kinship in remote regions (Marika et al. 2009, Holmes and Jampijinpa 2013). In more settled regions, they are reflected in the identities and remembered origins of descent groups (Sutton 1998b). Interlinkages and cross-cutting responsibilities mean that the authority of individual traditional owners to make decisions, alone or in concert with others, may be differentiated within IPAs either spatially, by gender, or by the nature of a particular threat or opportunity. These perspectives, although well established in anthropological literature, are much less understood by ecologists and natural resource managers involved in IPA management. They represent a strong shift away from the much criticized construct of community (Agrawal and Gibson 1999) that has been ubiquitous in Australian indigenous affairs policy (Davies 2003) and highlight the importance of engaging social scientists, notably anthropologists, in IPA planning to give appropriate attention to "the complexity of the social" (West and Brockington 2006:614).

Nevertheless, there is little information in IPA management plans about how members of IPA governing committees and boards, and their decisions, are actually influenced by the kinds of customary institutions noted above. Undoubtedly, one reason for this lack of specificity is that these institutions often provide for flexibility, negotiation, and contest (Myers 1986, Merlan 1997). Other complexities result from the impact of colonization and environmental change on social organization, property rights, and opportunities to maintain and pass on knowledge of country (Young 1987, Rose 1996). Such factors contribute to a prevalent view within nonindigenous Australia that indigenous ways of decision making are unknowable, immutable, and/or corrupt (Smith and Hunt 2011). Further attention, in future IPA plans, to explicating the basis on which particular people are the right and proper ones to make various kinds of decisions may contribute progressively to challenging this view.

Indigenous efforts to overcome the epistemological and scale limitations of colonial tenure boundaries through countrybased planning highlight the potential role of customary institutions as unifying frameworks for ecosystem management. Potentially, such frameworks might even extend beyond the territories of a particular language group. Networked and relational forms of indigenous Australian governance have been shown to link horizontally and vertically to larger collectivities and alliances and to be reformed by indigenous people where no longer fit for purpose (Smith and Hunt 2011). Such polycentric entities, linked across scale, are considered important for adaptive capacity (Olsson et al. 2004, Cundill and Fabricius 2010).

Nonetheless, the very flexibility that is inherent in customary institutions, most markedly in arid regions (Keen 2003), may present challenges for the conservation intent expressed in IPA plans. We do not know how effective IPA plans and governance structures will be in maintaining conservation intent when opportunities arise for resource rents from land uses, such as agistment livestock grazing or mining (O'Faircheallaigh 2011), which offer traditional owners greater financial benefit for less effort than is the case for conservation management. Understandings of human territoriality in nonequilibrium systems in which productivity varies stochastically (Dyson-Hudson and Smith 1978, Ellis and Swift 1988, Mearns 1993, Powell 1998, Davidson-Hunt and Berkes 2003) suggest that the flexible customary institutions that are engaged in IPA governance will form different configurations if pay-offs increase substantially. Such challenges indicate the potential importance of IPA plans as frameworks for resolution of conflicts among traditional owners. However, conflict resolution is a neglected area in IPA plans as it is more generally in indigenous Australian contexts (Bauman 2007).

Other challenges for IPA plans and planning are indicated in relation to development of adaptive comanagement, a promising approach to promoting resilience and sustainability in social-ecological systems that combines the learning emphasis of adaptive management and comanagement's emphasis on partnerships (Olsson et al. 2004, Berkes 2007, Fabricius et al. 2007, Armitage et al. 2009, Berkes 2009b, Schultz et al. 2011). A number of the IPA plans we examined signal traditional owners' intent to apply adaptive management. In accordance with IPA Program recommendations (AG 2012), some IPAs have modified the Australian Government's natural resource management program logic and evaluation framework (AG 2009), using it to reflect traditional owners' strategic priorities and to identify indicators that are culturally meaningful. A range of monitoring methods are in use in various IPAs including systematic surveys of animal movements supported by handheld data loggers (Ens et al. 2010, Wilson et al. 2010), elders' assessments about whether important sites are being properly looked after (Rodgers 2010), and, in Paruku IPA, periodic updating of large topographically accurate maps hand-painted by traditional owners to record observations of burnt areas and wildlife sightings (Paruku IPA 2010, Morton et al. 2013). The important role that learning has in the sustainability of social-ecological systems (Armitage et al. 2008) suggests a key need to better understand whether and how these mechanisms actually engage traditional owners in reflecting about the effectiveness of their management and adapting management directions. 
Partnerships have been found to be important for effective community-based conservation in other contexts (Berkes 2007, Fabricius et al. 2007). Extending and deepening IPA partnerships is critical and urgent because the IPA Program only provides seed funding for management, and its continuity beyond 2013 is not assured (ANAO 2011). Diverse and strong partner networks are well developed in some IPAs, such as Dhimurru IPA, which Yolgnu people declared after 20 years of partnership building by Dhimurru Land Management Aboriginal Corporation (Smyth 2007, Hoffmann et al. 2012), and Wardekkan IPA, declared in 2007 after a decade of research had enabled an agreement through which private sector investment resources traditional owners to manage fire, build on traditional practices, and achieve greenhouse gas mitigation targets (Whitehead et al. 2008, WLM 2010). However, partnership development is at a much earlier stage in many other IPAs.

The potential for the knowledge of traditional owners to be undermined and their authority and priorities subverted by the different epistemologies and agendas of partner organizations (Nadasdy 2003, Walker 2011, Gorman and Vemuri 2012, Muller 2012) has influenced at least two IPAs to emphasize that formation of IPA partnerships needs to wait until after traditional owners have established their IPA plan, or at least its core themes (Hoffmann et al. 2012, Preuss and Dixon 2012). Nevertheless, IPA planning processes are themselves invariably partnership processes because they involve collaboration and communication between traditional owners, planning facilitators, staff of the IPA Program, and often, bridging organizations. Robinson and Wallington's (2012) analysis of boundary work in the management of feral animals in a comanaged national park is indicative of the complexities that IPA planning facilitators face in translating meanings and brokering understandings. IPA plans, or the maps, diagrams, and vision statements included in them, might serve as boundary objects, that is, tools that are coproduced among various parties and that each party finds to be meaningful. Such objects have been valuable in other contexts, providing a shared point of reference for knowledge that various parties, individually or collectively, consider to be legitimate and authoritative, and acting to facilitate social learning and maintain trusted connections (Cash et al. 2003, 2006, Mollinga 2010). However, little consideration has been given to date to how IPA plans are received by IPA partners or prospective partners and what further innovations might be necessary for plans to play an effective role in building diverse and strong partnerships.

\section{CONCLUSION}

Development of a management plan has been integral to declarations made by 50 indigenous groups in Australia of their intent to manage all, or part of, their customary estates for conservation outcomes in perpetuity as IPAs. Four innovations distinguish some recent IPA management plans from earlier such plans and from those prepared for government-established protected areas: (1) overt recognition of the primacy of customary governance; (2) strategic planning formats that reflect interlinkages between people, place, plants, and animals; (3) planning frameworks that encompass customary territories, identify cross-scale issues, and challenge power relations embedded in colonial tenures; and (4) a suite of planning documents for varied audiences and purposes, with an emphasis in the main plan on visual and spatial communication modes that facilitate accessibility to traditional owners. Identification of these innovations contributes to addressing a lack of accessible guidance for ICCA management planning both within Australia and in other jurisdictions in which recognition of ICCAs as part of national protected area systems is at an earlier stage. Because they reflect indigenous ontologies, we consider that these innovations will promote confidence among traditional owners about maintaining control of IPA governance and management and drive integration of knowledge. These innovations are not widespread across existing IPA management plans, but their inclusion in management plan guidelines produced by the Australian Government IPA Program (Hill et al. 2012) will encourage their wider adoption and ongoing innovation.

Understanding the extent to which IPA plans are actually used to guide learning and adaptation warrants further investigation. Other important areas for inquiry include how plans might best contribute to resolving conflict among traditional owners, and how they might support the development of diverse and strong partnerships while managing risks of partners eroding local control. Research on such questions would valuably extend beyond the format and content of IPA plans, which has been our focus here, to encompass participatory action research on the dynamics of governance and management, and the impact of these processes on biodiversity conservation and livelihoods in ICCAs.

Responses to this article can be read online at: http://www.ecologyandsociety.org/issues/responses. php/5404

\section{Acknowledgments:}

We thank people and organizations who participated in the development of Australian national guidelines for IPA management plans. We also acknowledge the assistance of Bruce Rose, Noah Pleshet, Kim Mahood, Veronica Lulu, Jane Addison, Sam Muller, Sue Jackson, Erin Bohensky, James Butler, and two anonymous referees for comments and insights that helped us improve on earlier drafts of this paper, and Glenn Johnstone of the Australian Department of 
Sustainability, Environment, Water, Population, and Communities for preparing Figure 1.

\section{LITERATURE CITED}

Agrawal, A., and C. C. Gibson. 1999. Enchantment and disenchantment: the role of community in natural resource conservation. World Development 27(4):629-649. http://dx. doi.org/10.1016/S0305-750X(98)00161-2

Altman, J., G. Buchanan, and L. Larsen. 2007. The environmental significance of the indigenous estate: natural resource management as economic development in remote Australia. ANU Centre for Aboriginal Economic Policy Research Discussion Paper No. 286/2007, Centre for Aboriginal Economic Policy Research, Canberra, Australia. [online] URL: http://caepr.anu.edu.au/Publications/DP/2007DP286. php

Armitage, D. 2007. Building resilient livelihoods through adaptive co-management: the role of adaptive capacity. Pages 62-82 in D. Armitage, F. Berkes, and N. C. Doubleday, editors. Adaptive co-management: collaboration, learning and multilevel governance. UBC Press, Vancouver, British Columbia, Canada.

Armitage, D., M. Marschke, and R. Plummer. 2008. Adaptive co-management and the paradox of learning. Global Environmental Change 18(1):86-98. http://dx.doi.org/10.1016/ j.gloenvcha.2007.07.002

Armitage, D., R. Plummer, F. Berkes, R. I. Arthur, A. T. Charles, I. J. Davidson-Hunt, A. P. Diduck, N. C. Doubleday, D. S. Johnson, M. Marschke, P. McConney, E. W. Pinkerton, and E. K. Wollenberg. 2009. Adaptive co-management for social-ecological complexity. Frontiers in Ecology and the Environment 7(2):95-102. http://dx.doi.org/10.1890/070089

Australian Bureau of Statistics (ABS). 2010a. The Australian statistical geographic classification (ASGC) remoteness structure. Australian Bureau of Statistics, Canberra, Australia. [online] URL: http://www.abs.gov.au/websitedbs/d3310114. nsf/home/remoteness+structure

Australian Bureau of Statistics (ABS). 2010b. Experimental estimates and projections, aboriginal and Torres Strait islander Australians 1991-2021. Australian Bureau of Statistics, Canberra, Australia. [online] URL: http://www.abs. gov.au/ausstats/abs@.nsf/mf/3238.0

Australian Bureau of Statistics (ABS). 2010c. Population characteristics, aboriginal and Torres Strait islander Australians 2006. Australian Bureau of Statistics, Canberra, Australia. [online] URL: http://www.ausstats.abs.gov.au/ ausstats/subscriber.nsf/0/526FE126443EBCC6CA257718001D547F/ \$File/47130_2006_reissue.pdf
Australian Government (AG). 2009. Natural resource management monitoring evaluation reporting and improvement (MERI) framework. Caring for Our Country Program, Australian Government, Canberra, Australia.

Australian Government (AG). 2011. About the National Reserve System. Australian Government, Department of Sustainability Environment Water Population and Communities, Canberra, Australia. [online] URL: http://www.environment. gov.au/parks/nrs/index.html

Australian Government (AG). 2012. IPA manager's toolkit: monitoring and evaluation. Australian Government, Department of Sustainability, Environment, Water, Population and Communities, Canberra, Australia.

Australian National Audit Office (ANAO). 2011. The auditorgeneral audit report no. 14 2011/12 performance audit: indigenous protected areas. Department of Sustainability, Environment, Water, Population and Communities. Australian National Audit Office, Canberra, Australia. [online] URL: http://www.anao.gov.au/Publications/AuditReports/2011-2012/Indigenous-Protected-Areas

Australian State of the Environment Committee (ASEC). 2011. State of the environment 2011. Independent report to the Australian Government Minister for Sustainability, Environment, Water, Population and Communities. Australian State of the Environment Committee, Canberra, Australia. [online] URL: http://www.environment.gov.au/ soe/2011/report/key-findings.html\#key-findings

Axford, J. C., M. T. Hockings, and R. W. B. Carter. 2008. What constitutes success in Pacific Island community conserved areas? Ecology and Society 13(2): 45. [online] URL: http://www.ecologyandsociety.org/vol13/iss2/art45/

Bauman, T. 2007. 'You mob all agree?' The chronic emergency of culturally competent engaged indigenous problem solving. Indigenous Law Bulletin 6(29):13-15. [online] URL: http:// www.whatsworking.com.au/WomenforWik/pdfs/ILB v6n29 Bauman. pdf

Berkes, F. 2004. Rethinking community-based conservation. Conservation Biology 18(3):621-630. http://dx.doi.org/10.1111/ j.1523-1739.2004.00077.x

Berkes, F. 2007. Community-based conservation in a globalized world. Proceedings of the National Academy of Sciences of the United States of America 104 (39):15188-15193. http://dx.doi.org/10.1073/pnas.0702098104

Berkes, F. 2009a. Community conserved areas: policy issues in historic and contemporary context. Conservation Letters 2:20-25. http://dx.doi.org/10.1111/j.1755-263X.2008.00040. $\underline{\mathrm{X}}$ 
Berkes, F. 2009b. Evolution of co-management: role of knowledge generation, bridging organizations and social learning. Journal of Environmental Management 90 (5):1692-1702. http://dx.doi.org/10.1016/j.jenvman.2008.12.001

Berkes, F., J. Colding, and C. Folke. 2000. Rediscovery of traditional ecological knowledge as adaptive management. Ecological Applications 10(5):1251-1262. http://dx.doi. org/10.1890/1051-0761(2000)010[1251:ROTEKA]2.0.CO;2

Berkes, F., J. Colding, and C. Folke, editors. 2003. Navigating social-ecological systems: building resilience for complexity and change. Cambridge University Press, Cambridge, UK. http://dx.doi.org/10.1017/CBO9780511541957

Berry, H. L., J. R. A. Butler, C. P. Burgess, U. G. King, K. Tsey, Y. L. Cadet-James, C. W. Rigby, and B. Raphael. 2010. Mind, body, spirit: co-benefits for mental health from climate change adaptation and caring for country in remote aboriginal Australian communities. New South Wales Public Health Bulletin 21(6):139-145. http://dx.doi.org/10.1071/NB10030

Bird, R. B., D. W. Bird, B. F. Codding, C. H. Parker, and J. H. Jones. 2008. The "fire stick farming" hypothesis: Australian aboriginal foraging strategies, biodiversity, and anthropogenic fire mosaics. Proceedings of the National Academy of Sciences of the United States of America 105 (39):14796-14801. http://dx.doi.org/10.1073/pnas.0804757105

Bohensky, E. L., and Y. Maru. 2011. Indigenous knowledge, science, and resilience: what have we learned from a decade of international literature on "integration"? Ecology and Society 16(4): 6. [online] URL: http://www.ecologyandsociety. org/vol16/iss4/art6/

Borrini-Feyerabend, G. 2008. Implementing the CBD program of work on protected areas: governance as key for effective and equitable protected area systems. Briefing Note 8. Commission on Environmental Economic and Social Policy, IUCN, Geneva, Switzerland. [online] URL: http://cmsdata. iucn.org/downloads/governance of protected areas for cbd pow briefing note 08 1.pdf

Bradley, J., and Yanyuwa Families. 2007. Barni-Wardimantha Awara Yanyuwa sea country plan. Mabunji Aboriginal Resource Association, Borroloola, Northern Territory, Australia. [online] URL: http://www.environment.gov.au/ indigenous/publications/pubs/yanyuwa.pdf

Burbidge, A. A., K. A. Johnson, P. J. Fuller, and R. I. Southgate. 1988. Aboriginal knowledge of the mammals of the central deserts of Australia. Australian Wildlife Research 15:9-39. http://dx.doi.org/10.1071/WR9880009

Burgess, C. P., F. H. Johnston, H. Berry, J. McDonnell, D. Yibarbuk, C. Gunabarra, A. Mileran, and R. Bailie. 2009. Healthy country, healthy people: superior indigenous health outcomes are associated with 'caring for country.' Medical Journal of Australia 190(10):567-572.

Carter, J. 2010. Protocols, particularities, and problematising indigenous 'engagement' in community-based environmental management in settled Australia. Geographical Journal 176 (3):199-213. http://dx.doi.org/10.1111/j.1475-4959.2010.00355. $\underline{x}$

Carter, J., and D. Hollinsworth. 2009. Segregation and protectionism: institutionalised views of aboriginal rurality. Journal of Rural Studies 25(4):414-424. http://dx.doi. org/10.1016/j.jrurstud.2009.05.008

Cash, D. W., W. N. Adger, F. Berkes, P. Garden, L. Lebel, P. Olsson, L. Pritchard, and O. Young. 2006. Scale and crossscale dynamics: governance and information in a multilevel world. Ecology and Society 11(2): 8. [online] URL: http:// www.ecologyandsociety.org/vol11/iss2/art8/

Cash, D. W., W. C. Clark, F. Alcock, N. M. Dickson, N. Eckley, D. H. Guston, J. Jäger, and R. B. Mitchell. 2003. Knowledge systems for sustainable development. Proceedings of the National Academy of Sciences of the United States of America 100(14):8086-8091. http://dx.doi.org/10.1073/ pnas. 1231332100

Christie, M. J., and B. Perrett. 1996. Negotiating resources: language, knowledge and the search for 'secret English' in northeast Arnhem Land. Pages 57-65 in R. Howitt, J. Connell, and P. Hirsch, editors. Resources, nations and indigenous peoples. Oxford University Press, Melbourne, Australia.

Clarke, P. 1999. Park management planning in Africa. Oryx 33(4):281-284.

Clarke, J. E. 2000. Protected area management planning. Oryx 34(2):85-89.

Cundill, G., and C. Fabricius. 2010. Monitoring the governance dimension of natural resource comanagement. Ecology and Society 15(1): 15. [online] URL: http://www. ecologyandsociety.org/vol15/iss1/art15/

Davidson-Hunt, I. J., and F. Berkes. 2002. Nature and society through the lens of resilience: toward a human-in-ecosystem perspective. Pages 53-72 in F. Berkes, J. Colding, and C. Folke, editors. Navigating social-ecological systems: building resilience for complexity and change. Cambridge University Press, Cambridge, UK. http://dx.doi.org/10.1017/ CBO9780511541957.006

Davies, J. 2003. Contemporary geographies of indigenous rights and interests in rural Australia. Australian Geographer 34(1):19-45. http://dx.doi.org/10.1080/00049180320000066137

Davies, J., D. Campbell, M. Campbell, J. Douglas, H. Hueneke, M. LaFlamme, D. Pearson, K. Preuss, J. Walker, 
and F. Walsh. 2011. Attention to four key principles can promote health outcomes from desert aboriginal land management. Rangeland Journal 33(4):417-431. http://dx. doi.org/10.1071/RJ11031

Dearden, P., M. Bennett, and J. Johnston. 2005. Trends in global protected area governance, 1992-2002. Environmental Management 36(1):89-100. http://dx.doi.org/10.1007/ s00267-004-0131-9

Dhimurru Aboriginal Corporation, Wearne Advisors, and S. Muller. 2008. Dhimurru IPA plan of management, 2008 to 2015. Dhimurru Aboriginal Corporation, Nhulunbuy, Northern Territory, Australia. [online] URL: http://www. dhimurru.com.au/uploads/8/9/3/6/8936577/dhimurru pom 2008 to 20150812211 res.pdf

Douglas, J. 2011. Learning from country: the value of indigenous language and culture programs in remote schools for community engagement and natural resource management. Ninti One Research Report 69, Ninti One, Alice Springs, Australia. [online] URL: http://www.nintione.com. au/resource/NintiOneResearchReport 69 Thevalueofcountryvisitsinremoteschools.pdf

Dudley, N. 2008. Guidelines for applying protected area management categories. IUCN, Gland, Switzerland. http://dx. doi.org/10.2305/IUCN.CH.2008.PAPS.2.en

Dyson-Hudson, R., and E. A. Smith. 1978. Human territoriality: an ecological reassessment. American Anthropologist 80(1):21-41. http://dx.doi.org/10.1525/ aa.1978.80.1.02a00020

Ellis, J. E., and D. M. Swift. 1988. Stability of African pastoral ecosystems: alternate paradigms and implications for development. Journal of Range Management 41(6):450-459. http://dx.doi.org/10.2307/3899515

Ens, E.-J., P. Cooke, R. Nadjamerrek, S. Namundja, V. Garlngarr, and D. Yibarbuk. 2010. Combining aboriginal and non-aboriginal knowledge to assess and manage feral water buffalo impacts on perennial freshwater springs of the aboriginal-owned Arnhem Plateau, Australia. Environmental Management 45(4):751-758. http://dx.doi.org/10.1007/ $\underline{\text { s00267-010-9452-Z }}$

Ens, E.-J., M. Finlayson, K. Preuss, S. Jackson, and S. Holcombe. 2012. Australian approaches for managing 'country' using indigenous and non-indigenous knowledge. Ecological Management and Restoration 13(1):100-107. http://dx.doi.org/10.1111/j.1442-8903.2011.00634.x

Fabricius, C., C. Folke, G. Cundill, and L. Schultz. 2007. Powerless spectators, coping actors, and adaptive comanagers: a synthesis of the role of communities in ecosystem management. Ecology and Society 12(1): 29. [online] URL: http://www.ecologyandsociety.org/vol12/iss1/art29/
Fallding, M. 2000. What makes a good natural resource management plan? Ecological Management and Restoration 1(3):185-194. http://dx.doi.org/10.1046/j.1442-8903.2000.00031. $\underline{\mathrm{X}}$

Finn, M., and S. Jackson. 2011. Protecting indigenous values in water management: a challenge to conventional environmental flow assessments. Ecosystems 14(8):1232-1248. http://dx.doi.org/10.1007/s10021-011-9476-0

Gilligan, B. 2006. The indigenous protected areas program: 2006 evaluation. Australian Government, Department of Sustainability, Environment, Water, Population and Communities, Canberra. Australia. [online] URL: http:// www.environment.gov.au/indigenous/publications/ipa-evaluation. $\underline{\mathrm{html}}$

Gorman, J., and S. Vemuri. 2012. Social implications of bridging the gap through 'caring for country' in remote indigenous communities of the Northern Territory, Australia. Rangeland Journal 34(1):63-73. http://dx.doi.org/10.1071/ $\underline{\text { RJ11037 }}$

Gorman, J. T., P. Whitehead, A. D. Griffiths, and L. Petheram. 2008. Production from marginal lands: indigenous commercial use of wild animals in northern Australia. International Journal of Sustainable Development and World Ecology 15(3):240-250. http://dx.doi.org/10.3843/SusDev.15.3:7

Henrich, J., S. J. Heine, and A. Norenzayan. 2010. The weirdest people in the world? Behavioral and Brain Sciences 33(2-3):61-83.

Hibbard, M., M. B. Lane, and K. Rasmussen. 2008. The split personality of planning: indigenous people and planning for land and resource management. Journal of Planning Literature 23(2):136-151. http://dx.doi.org/10.1177/088541$\underline{2208322922}$

Hill, R., C. Grant, M. George, C. J. Robinson, S. Jackson, and N. Abel. 2012. A typology of indigenous engagement in Australian environmental management: implications for knowledge integration and social-ecological system sustainability. Ecology and Society 17(1): 23. http://dx.doi. org/10.5751/ES-04587-170123

Hill, R., F. Walsh, J. Davies, and M. Sandford. 2011. Our country our way: guidelines for Australian indigenous protected area management plans. Australian Government, Department of Sustainability, Environment, Water, Population and Communities, Canberra, Australia. [online] URL: http://www.environment.gov.au/indigenous/ipa/toolkit/ management.html

Hoffmann, B. D., S. Roeger, P. Wise, J. Dermer, B. Yunupingu, D. Lacey, D. Yunupingu, B. Marika, M. Marika, and B. Panton. 2012. Achieving highly successful multiple agency collaborations in a cross-cultural environment: 
experiences and lessons from Dhimurru Aboriginal Corporation and partners. Ecological Management and Restoration 13(1):42-50. http://dx.doi.org/10.1111/

j.1442-8903.2011.00630.x

Holcombe, S., P. Yates, and F. Walsh. 2011. Reinforcing alternative economies: self-motivated work by central Anmatyerr people to sell Katyerr (desert raisin, bush tomato) in central Australia. Rangeland Journal 33(3):255-265. http:// dx.doi.org/10.1071/RJ10081

Holmes, M. C. C., and W. (S. P.) Jampijinpa. 2013. Law for country: the structure of Warlpiri ecological knowledge and its application to natural resource management and ecosystem stewardship. Ecology and Society, in press.

Hunt, J. 2010. Looking after country in New South Wales: two case studies of socioeconomic benefits for aboriginal people. ANU Centre for Aboriginal Economic Policy Research Working Paper No. 75/2010, Centre for Aboriginal Economic Policy Research, Canberra, Australia. [online] URL: http:// caepr.anu.edu.au/Publications/WP/2010WP75.php

Hunt, J., J. Altman, and K. May. 2009. Social benefits of aboriginal engagement in natural resource management. ANU Centre for Aboriginal Economic Policy Research Working Paper 60/2009, Centre for Aboriginal Economic Policy Research, Canberra, Australia. [online] URL: http:// caepr.anu.edu.au/Publications/WP/2009WP60.php

Indigenous Land Corporation (ILC). 2011. Annual report 2010-11. Indigenous Land Corporation, Adelaide. Australia. [online] URL: http://www.ilc.gov.au/webdata/resources/ files/ILC_Annual_Report_2010-11.pdf

Ingold, T. 2000. The perception of the environment: essays on livelihood, dwelling and skill. Routledge, Oxon, UK.

Innes, J. E., and D. E. Booher. 2010. Planning with complexity: an introduction to collaborative rationality for public policy. Routledge, Oxon, UK.

International Union for Conservation of Nature (IUCN). 2009. Indigenous and community conserved areas: a bold new frontier for conservation. IUCN, Geneva, Switzerland. [online] URL: www.iucn.org/about/union/commissions/ ceesp/topics/governance/icca/

Keen, I. 2003. Aboriginal economy and society: Australia at the threshold of colonisation. Oxford University Press, South Melbourne, Australia.

Koenig, J., J. Altman, and A. D. Griffiths. 2011. Indigenous livelihoods and art income: participation, production and returns from woodcarvings in Arnhem Land, north Australia. Australian Geographer 42(4):351-369. http://dx.doi. org/10.1080/00049182.2011.619952
Kothari, A. 2006. Community conserved areas. Pages 549-573 in M. Lockwood, G. L. Worboys, and A. Kothari, editors. Managing protected areas: a global guide. Earthscan, London, UK.

Kumar, R. 2005. Research methodology. Pearson Education Australia, Frenchs Forest, Australia.

Lane, M. B. 2006. The role of planning in achieving indigenous land justice and community goals. Land Use Policy 23(4):385-394. http://dx.doi.org/10.1016/j.landusepol.2005.05.001

Leverington, F., K. L. Costa, H. Pavese, A. Lisle, and M. Hockings. 2010. A global analysis of protected area management effectiveness. Environmental Management 46 (5):685-698. http://dx.doi.org/10.1007/s00267-010-9564-5

Leverington, F., M. T. Hockings, and K. Lemos Costa. 2008. Management effectiveness evaluation in protected areas - a global study. Report for the project 'global study into management effectiveness evaluation of protected areas'. The University of Queensland, Gatton, IUCN WCPA, TNC, WWF, Australia. [online] URL: http://www.wdpa.org/ME/ PDF/global_study.pdf

Locke, H., and P. Dearden. 2005. Rethinking protected area categories and the new paradigm. Environmental Conservation 32(1):1-10. http://dx.doi.org/10.1017/ S0376892905001852

Lockwood, M. 2006. Management planning. Pages 292-327 in M. Lockwood, G. L. Worboys, and A. Kothari, editors. Managing protected areas: a global guide. Earthscan, London, UK.

Lockwood, M. 2010. Good governance for terrestrial protected areas: a framework, principles and performance outcomes. Journal of Environmental Management 91 (3):754-766. http://dx.doi.org/10.1016/j.jenvman.2009.10.005

Luckert, M. K., B. M. Campbell, J. T. Gorman, and S. T. Garnett, editors. 2007. Investing in indigenous natural resource management. Charles Darwin University Press, Darwin, Australia.

Mandingalbay Yidinji Aboriginal Corporation (MYAC). 2006. Strategic plan for Mandingalbay Yidinji country. Mandingalbay Yidinji Aboriginal Corporation, Gordonvale, Queensland, Australia.

Marika, R., Y. Yunupingu, R. Marika-Mununggiritj, and S. Muller. 2009. Leaching the poison - the importance of process and partnership in working with Yolngu. Journal of Rural Studies 25(4):404-413. http://dx.doi.org/10.1016/j. jrurstud.2009.05.007

Maru, Y. T., and V. H. Chewings. 2011. A review of measurement and causal analysis of indigenous poverty and 
disadvantage in remote indigenous Australia. CSIRO SocioEconomics and the Environment in Discussion (SEED) Working Paper Series Number 2011-02, Commonwealth Scientific and Industrial Research Organisation, Clayton South, Australia. [online] URL: http://www.csiro.au/ resources/SEED-paper-44.html

Maru, Y. T., and J. Davies. 2011. Supporting cross-cultural brokers is essential for employment among aboriginal people in remote Australia. Rangeland Journal 33(4):327-338. http:// dx.doi.org/10.1071/RJ11022

Mearns, R. 1993. Territoriality and land tenure among Mongolian pastoralists: variation, continuity and change. Nomadic Peoples (33):73-103. [online] URL: http://cnp. nonuniv.ox.ac.uk/pdf/NP journal back issues/

Territoriality_and_land_tenure_among_Mongolian_pastoralists R Mearns.pdf

Merlan, F. 1997. Fighting over country: four commonplaces. Pages 1-14 in D. E. Smith and J. Finlayson, editors. Fighting over country: anthropological perspectives. Centre for Aboriginal Economic Policy Research, Canberra, Australia. [online] URL: http://caepr.anu.edu.au/sites/default/files/ Publications/mono/CAEPR Mono12.pdf

Millenium Ecosystem Assessment (MEA). 2003. Ecosystems and human well-being: a framework for assessment. Island Press, Washington, D.C., USA. [online] URL: http://www. millenniumassessment.org/en/Framework.aspx

Mollinga, P. P. 2010. Boundary work and the complexity of natural resources management. Crop Science 50(2):S1-S9.

Moorcroft, H., E. Ignjic, S. Cowell, J. Goonack, S. Mangolomara, J. Oobagooma, R. Karadada, D. Williams, and N. Waina. 2012. Conservation planning in a cross-cultural context: the Wunambal Gaambera healthy country project in the Kimberley, western Australia. Ecological Management and Restoration 13(1):16-25. http://dx.doi.org/10.1111/ j.1442-8903.2011.00629.x

Morton, S., M. Martin, K. Mahood, and J. Carty, editors. 2013. Desert lake: art, science and stories from Paruku. CSIRO Publishing, Melbourne, Australia.

Muller, S. 2008. Accountability constructions, contestations and implications: insights from working in a Yolngu crosscultural institution, Australia. Geography Compass 2 (2):395-413. http://dx.doi.org/10.1111/j.1749-8198.2007.00087. $\underline{\mathrm{X}}$

Muller, S. 2012. 'Two ways': bringing indigenous and nonindigenous knowledges together. Pages 59-79 in J. Weir, editor. Country, native title and ecology. Australian National University e-press and Aboriginal History Incorporated (Monograph 24), Canberra, Australia. [online] URL: http:// epress.anu.edu.au/apps/bookworm/view/country,+native+title+ and+ecology/8681/ch04.html

Myers, F. R. 1986. Pintupi country, Pintupi self. Smithsonian Institute Press and Australian Institute of Aboriginal Studies, Washington, D.C., USA, and Canberra, Australia.

Nadasdy, P. 2003. Reevaluating the co-management success story. Arctic 56(4):367-380. [online] URL: http://arctic. synergiesprairies.ca/arctic/index.php/arctic/article/view/634

Nature Conservancy (TNC). 2006. CAP (Conservation Action Planning): an adaptive management framework. The Nature Conservancy, Arlington, Virginia, USA. [online] URL: http:// conserveonline.org/workspaces/cbdgateway/cap/practices/index html

O'Faircheallaigh, C. 2011. Use and management of revenues from indigenous-mining company agreements: theoretical perspectives. Working Paper Series No1/2011, Agreements Treaties and Negotiated Settlements Project, Melbourne, Australia. [online] URL: http://www.atns.net.au/atns/ references/attachments/ATNSWP1 2011 OFaircheallaigh.pdf

Olsson, P., C. Folke, and F. Berkes. 2004. Adaptive comanagement for building resilience in social-ecological systems. Environmental Management 34(1):75-90. http://dx. doi.org/10.1007/s00267-003-0101-7

Oltremari, J. V., and K. D. Thelen. 2003. Evolution of the planning process for protected areas in Latin America. Natural Areas Journal 23(2):174-179.

Paruku IPA. 2010. Paruku IPA management plan 2010-2020. Ngurra man martangangku marrkangu - keep your country and your culture strong. Paruku IPA Mulan office and Billiluna office, Halls Creek, Australia.

Peterson, N. 2005. What can the pre-colonial and frontier economies tell us about engagement with the real economy? Indigenous life projects and the conditions for development. Pages 7-18 in D. Austin-Broos and G. Macdonald, editors. Culture, economy and governance in aboriginal Australia: proceedings of a workshop of the Academy of the Social Sciences in Australia held at the University of Sydney 30 November-1 December 2004. Sydney University Press, Sydney, Australia.

Phillips, A. 2003. Turning ideas on their head: the new paradigm for protected areas. George Wright Forum 20 (2):11-32. [online] URL: http://www.uvm.edu/ snrsprng/ vermont.pdf

Powell, N. 1998. Co-management in non-equilibrium systems: cases from Namibian rangelands. Dissertation. Swedish University of Agricultural Sciences, Uppsala, Sweden.

Preuss, K., and M. Dixon. 2012. 'Looking after country twoways': insights into indigenous community-based conservation 
from the southern Tanami. Ecological Management and Restoration 13(1):2-15. http://dx.doi.org/10.1111/

j.1442-8903.2011.00631.X

Prober, S. M., M. H. O'Connor, and F. J. Walsh. 2011. Australian aboriginal peoples' seasonal knowledge: a potential basis for shared understanding in environmental management. Ecology and Society 16(2): 12. [online] URL: http://www.ecologyandsociety.org/vol16/iss2/art12/

Raymond, C. M., B. A. Bryan, D. H. MacDonald, A. Cast, S. Strathearn, A. Grandgirard, and T. Kalivas. 2009. Mapping community values for natural capital and ecosystem services. Ecological Economics 68(5):1301-1315. http://dx.doi. org/10.1016/j.ecolecon.2008.12.006

Ritchie, D. 2009. Things fall apart: the end of an era of systematic indigenous fire management. Pages 23-40 in J. Russell-Smith, P. Whitehead, and P. Cooke, editors. Culture, ecology and economy of fire management in north Australian savannas: rekindling the Wurrk tradition. CSIRO Publishing, Melbourne, Australia.

Robinson, C. J., D. Smyth, and P. J. Whitehead. 2005. Bush tucker, bush pets, and bush threats: cooperative management of feral animals in Australia's Kakadu National Park. Conservation Biology 19(5):1385-1391. http://dx.doi. org/10.1111/j.1523-1739.2005.00196.x

Robinson, C. J., and T. J. Wallington. 2012. Boundary work: engaging knowledge systems in co-management of feral animals on indigenous lands. Ecology and Society 17(2): 16. http://dx.doi.org/10.5751/ES-04836-170216

Rodgers, C. 2010. Yalata Indigenous Protected Area: draft MERI plan - monitoring, evaluation, reporting, improvement 2011-2016. Draft 2. Prepared by Carla Rogers of Evolve Communities for Yalata Community Incorporated Yalata, South Australia. [online] URL: http://www.environment.gov. au/indigenous/ipa/toolkit/pubs/meri-yalata.pdf

Rose, D. B. 1996. Nourishing terrains: Australian aboriginal views of landscape and wilderness. Australian Heritage Commission, Canberra, Australia. [online] URL: http://www. environment.gov.au/heritage/ahc/publications/commission/books/ pubs/nourishing-terrains.pdf

Ross, H., C. Grant, C. J. Robinson, A. Izurieta, D. Smyth, and P. Rist. 2009. Co-management and indigenous protected areas in Australia: achievements and ways forward. Australasian Journal of Environmental Management 16(4):242-252.

Schultz, L., A. Duit, and C. Folke. 2011. Participation, adaptive co-management, and management performance in the world network of Biosphere Reserves. World Development 39(4):662-671. http://dx.doi.org/10.1016/j.worlddev.2010.09.014

Sithole, B., H. Hunter-Xenie, L. Williams, J. Saegenschnitter, D. Yibarbuk, M. Ryan, O. Campion, B. Yunupingu, M. Liddy,
E. Watts, C. Daniels, G. Daniels, P. Christophersen, V. Cubillo, E. Phillips, W. Marika, D. Jackson, and W. Barbour. 2008. Aboriginal land and sea management in the Top End: a community-driven evaluation. CSIRO, Darwin, Australia. [online] URL: www.csiro.au/files/files/plcc.pdf

Smith, M. Stafford. 2008. The 'desert syndrome': causallylinked factors that characterise outback Australia. Rangeland Journal 30(1):3-14.

Smith, D., and J. Hunt. 2011. Understanding and engaging with indigenous governance: research evidence and possibilities for a dialogue with Australian governments. Journal of Australian Indigenous Issues 14(2-3):30-53.

Smyth, D. 2007. Dhimurru Indigenous Protected Area: sole management with partners. Pages 100-126 in T. Bauman and D. Smyth, editors. Indigenous partnerships in protected area management in Australia: three case studies. Australian Institute of Aboriginal and Torres Strait Islander Studies, Canberra, Australia.

Smyth, D. 2008. Just add water? Taking indigenous protected areas into sea country. Pages 95-110 in D. Smyth and G. Ward, editors. Protecting country: indigenous governance and management of protected areas. Proceedings of the AIATSIS Conference 2007. Australian Institute of Aboriginal and Torres Strait Islander Studies, Canberra, Australia. [online] URL: http://www.aiatsis.gov.au/research/publications/ ProtectingCountry8.pdf

Smyth, D. 2011. Review of working on country and indigenous protected area programs through telephone interviews: final report. Smyth and Bahrdt Consultants, Atherton, Australia. [online] URL: http://www.environment.gov.au/indigenous/ workingoncountry/publications/woc-interviews.html

Stanner, W. E. H. 1965. Aboriginal territorial organization: estate, range, domain and regime. Oceania 36(1):1-26.

Steering Committee for the Review of Government Service Provision (SCRGSP). 2011. Overcoming indigenous disadvantage: key indicators 2011. Productivity Commission, Canberra, Australia. [online] URL: http://www.pc.gov.au/ data/assets/pdf file/0018/111609/key-indicators-2011-report. pdf

Stoll-Kleemann, S. 2010. Evaluation of management effectiveness in protected areas: methodologies and results. Basic and Applied Ecology 11(5):377-382. http://dx.doi. org/10.1016/j.baae.2010.06.004

Sutton, P. 1998a. Icons of country: topographic representation of classical aboriginal traditions. Pages 352-386 in D. Woodward and G. M. Lewis, editors. The history of cartography: cartography in the traditional African, American, Arctic, Australian, and Pacific societies. University of Chicago Press, Chicago, Illinois, USA. [online] URL: http:// 
www.press.uchicago.edu/books/HOC/HOC_V2_B3/ HOC VOLUME2 Book3 chapter9.pdf

Sutton, P. 1998b. Native title and the descent of rights. National Native Title Tribunal, Perth, Australia.

Szabo, S., and D. Smyth. 2003. Indigenous protected areas in Australia: incorporating ondigenous owned land into Australia's national system of protected areas. Pages 145-164 in H. Jaireth and D. Smyth, editors. Innovative governance: indigenous peoples, local communities and protected areas. Ane Books, New Delhi, India.

Taylor, A., S. Larson, N. Stoeckl, and D. Carson. 2011. The haves and have nots in Australia's tropical north: new perspectives on a persisting problem. Geographical Research 49(1):13-22. http://dx.doi.org/10.1111/j.1745-5871.2010.00648. $\underline{\mathrm{X}}$

Thackway, R., S. Szabo, and D. Smyth. 1996. Indigenous protected areas: a new concept in biodiversity conservation. Pages 18-34 in R. Longmore, editor. Biodiversity: broadening the debate 4. Australian Nature Conservation Agency, Canberra, Australia.

Thomas, L., and J. Middleton. 2003. Guidelines for management planning of protected areas. World Commission on Protected Areas best practice protected area guidelines series No 10, IUCN, Gland, Switzerland.

Tobias, T. 2010. Living proof: the essential data collection guide for indigenous land use and occupancy map surveys. Ecotrust Canada, Vancouver, British Columbia, Canada.

Walker, J. 2011. Processes for effective management: learning from the northern Tanami IPA. Dissertation. School of Social Policy, Charles Darwin University, Darwin, Australia.

Walsh, F. 2009. To hunt and to hold: Martu aboriginal people's uses and knowledge of their country, with implications for comanagement in Karlamilyi (Rudall River) National Park and the Great Sandy Desert, western Australia. Dissertation. Department of Anthropology and Department of Plant Biology, University of Western Australia, Perth, Australia.

Walsh, F., J. Davies, and R. Hill. 2011. Report of workshop to develop national guidelines for indigenous protected area plans, Alice Springs Desert Park, June 2010 [CD-ROM]. CSIRO and the Department of Sustainability, Environment, Water, Population and Communities, Canberra, Australia.

Walsh, F., and P. Mitchell, editors. 2002. Planning for country: cross-cultural approaches to decision making on aboriginal lands. Jukurrpa Books/IAD Press, Alice Springs, Australia.

Warddeken Land Management Ltd. (WLM). 2010. Annual report 2009-10. Warddekan Land Management Ltd., Kabulwarnamyo, Northern Territory, Australia. [online]
URL: http://caepr.anu.edu.au/sites/default/files/ cck misc documents/2011/01/Warddeken\%20AR\%202009-2010\% 20web.pdf

Waylen, K. A., A. Fischer, P. J. K. McGowan, S. J. Thirgood, and E. J. Milner-Gulland. 2010. Effect of local cultural context on the success of community-based conservation interventions. Conservation Biology 24(4):1119-1129. http:// dx.doi.org/10.1111/j.1523-1739.2010.01446.x

West, P., and D. Brockington. 2006. An anthropological perspective on some unexpected consequences of protected areas. Conservation Biology 20(3):609-616. http://dx.doi. org/10.1111/j.1523-1739.2006.00432.x

Whitehead, P. J., P. Purdon, J. Russell-Smith, P. M. Cooke, and S. Sutton. 2008. The management of climate change through prescribed savanna burning: emerging contributions of indigenous people in northern Australia. Public Administration and Development 28(5):374-385. http://dx. doi.org/10.1002/pad.512

Wilson, G. R., M. J. Edwards, and J. K. Smits. 2010. Support for indigenous wildlife management in Australia to enable sustainable use. Wildlife Research 37:256-263.

Wilson, G. R., A. Knight, and L. Liddle. 2004. Increasing the numbers of wildlife preferred by aboriginal communities in the Anangu Pitjantjatjara Lands, Australia. Game and Wildlife Science 21(4):687-695. [online] URL: http://www.awt.com. au/wp-content/uploads/2009/06/Game-Science-paper-on-APWildlife-mgt.pdf

Wilson, G. R., M. Pickering, and G. Kay. 2005. Angas Downs Indigenous Protected Area plan of management. Report to Lisanote Pty Ltd, Australian Wildlife Services, Canberra, Australia.

Wilson, G. R., and M. Woodrow. 2009. Kuka kanyini: Australian indigenous adaptive management. Pages 117-141 in C. Allan and G. H. Stankey, editors. Adaptive environmental management: a practitioner's guide. Springer Science and Business, Dordrecht, The Netherlands and CSIRO Publishing, Collingwood, Australia.

Woodward, E. 2008. Social networking for aboriginal land management in remote northern Australia. Australasian Journal of Environmental Management 15(4):241-252. http:// dx.doi.org/10.1080/14486563.2008.10648753

Young, E. 1987. Resettlement and caring for the country: the Anmatyerre experience. Aboriginal History 11:156-170. 